\title{
Cryopreservation of Swamp Buffalo Semen in Skim Milk Yolk-based Diluent with Two Different Cryoprotectants
}

\author{
M.T. Herbowo ${ }^{a}$, R.I. Arifiantini ${ }^{b, *}$, N.W.K Karja ${ }^{b}$, \& R.G. Sianturic \\ aSingosari Artificial Insemination Centre, \\ Toyomarto, Singosari, Malang, East Java 65153 \\ 'Division of Reproduction and Obstetric, Department of Veterinary Clinic, Reproduction and Pathology, \\ Faculty of Veterinary Medicine, Bogor Agricultural University, \\ Jalan Agatis Kampus IPB Dramaga, Bogor 16680, Indonesia \\ 'Indonesian Research Institute for Animal Production \\ Jalan Raya Tapos No. 36, Banjar Waru, Ciawi, Bogor, 16720, Indonesia \\ ${ }^{*}$ Corresponding author: iis.arifiantinipurna@gmail.com \\ (Received 18-05-2018; Revised 04-12-2018; Accepted 17-12-2018)
}

\begin{abstract}
The successful of artificial insemination (AI) in buffalo is still low. The quality of frozen semen determines the successful of AI program. Glycerol is widely used for cryopreservation of buffalo semen with unsatisfactory results due to its toxicity and antifertility properties. This study aimed to investigate the effect of glycerol and dimethylformamide (DMF) concentrations in skim milk egg yolk (SMEY)-based diluent on the quality of frozen-thawed swamp buffalo bull semen. Fresh semen was divided into eight aliquots. Each aliquot was diluted in SMEY containing $4 \%, 5 \%, 6 \%$, and $7 \%$ glycerol and $4 \%, 5 \%, 6 \%$, and $7 \%$ DMF. Diluted semen was packed into mini straw $(0.25 \mathrm{~mL})$, equilibrated at $4{ }^{\circ} \mathrm{C}$ for 4 hours, frozen in liquid nitrogen vapor for 10 minutes, and stored at liquid nitrogen container. The straws were thawed after 24 hours at $37^{\circ} \mathrm{C}$ for 30 seconds for evaluation. The results showed that the post thawed sperm motility and recovery rate in SMEY extender containing $7 \%$ glycerol and 5\% DMF were higher than the other glycerol or DMF concentrations. Post thawed sperm viability and plasma membrane integrity in SMEY containing 4\%-6\% DMF did not differ significantly, however both values were higher than those in 7\% DMF. Post thawed sperm viability and plasma membrane integrity did not differ between SMEY containing $6 \%$ and $7 \%$ glycerol. However, both values were higher than those in $4 \%$ and $5 \%$ glycerol. It is concluded that $7 \%$ glycerol or $5 \%$ DMF is considered to be the most suitable cryoprotective agent for swamp buffalo semen cryopreservation.
\end{abstract}

Keywords: cryprotective agent; dimethylformamide; glycerol; sperm; swamp buffalo

\section{INTRODUCTION}

Artificial insemination (AI) is the most important reproductive biotechnology that can be applied widely for dissemination of superior genetic material of males (Singh \& Balhara, 2016). The quality of frozen semen is a major determinant to the successful of AI program. However, the use of frozen semen for AI in buffalo does not produce the same success as in cattle (Gordon, 1996). The successful of AI program in buffalo is approximately 25\%-40\% (Paul \& Prakash, 2005; Baruselli et al., 2007; Hoque et al., 2014; Rossi et al., 2014). Therefore, a suitable semen freezing and handling technique needs to be developed. Using cauda epididymal spermatozoa, Yulnawati et al. (2013) reported that tris-based and citrate-based extenders had similar ability to maintain the epididymal sperm quality and its fertilizing capacity in spotted buffalo. The addition of taurine or trehalose to the freezing extender was reported to reduce cryodamage in the buffalo spermatozoa (Reddy et al., 2010).
Akther et al. (2010) also report that the commercially available Bioxcell@ can be used for the cryopreservation of buffalo semen with an equal efficiency to tris-citric egg yolk extender.

The quality of frozen semen is determined by the freezing technique, extender, as well as the type and concentration of cryoprotective agent. Glycerol is a widely used cryoprotective agent (CPAs) for buffalo semen cryopreservation (Sianturi et al., 2012; Shahverdi et al., 2014; Kumar et al., 2016). Razul et al. (2007) reported that $6 \%$ glycerol added at $37^{\circ} \mathrm{C}$ provided a better cryoprotection to the motility apparatus and plasma membrane integrity of buffalo sperm. Glycerol as an intracellular CPAs permeates into the cells to prevent ice crystal formation. Despite its benefits, some studies reported that glycerol induced physicochemical alteration that led to plasma membrane rupture, removal of membrane protein, and acrosome damage which would reduce the sperm fertility (Macias-Garcia et al., 2012).

Amide was suggested as an alternative CPAs for 
semen cryopreservation especially for those which sensitive to glycerol due to its lower toxicity and lower molecular weight (Bezerra et al., 2011). Dimethylformamide (DMF) is one of amide that widely utilized as an intracellular CPAs for semen cryopreservation in several domestic animals such as equine (Arifiantini et al., 2007; Gibb et al., 2013), caprine (Bezerra et al., 2011; Ariantie et al., 2013), and cattle (Oh et al., 2012). The objective of this study was to determine the most suitable CPAs and its best concentration in skim milk egg yolk extender on the quality of post thawed swamp buffalo semen.

\section{MATERIALS AND METHODS}

\section{Animals}

Two sexually matured, healthy, and with normal libido swamp buffalo bulls of about 7 and 10 years of age were used in this study. The bulls were kept at Indonesian Research Institute for Animal Production (Ciawi, West Jawa, Indonesia) under the optimum nutritional and housing conditions. Each bull was fed with forages at the level of $10 \%$ of body weight and 4 $\mathrm{kg}$ concentrate on the daily basis. Water was provided ad libitum.

\section{Preparation of Extender}

Skim milk egg yolk extender (SMEY) was prepared by dissolving $10 \mathrm{~g}$ of skim milk powder (Tropicana Slim) and $1 \mathrm{~g}$ of fructose (Merck, KgaA, Darmstadt Germany) in $100 \mathrm{~mL}$ of distilled water. The mixture was then heated at $92{ }^{\circ} \mathrm{C}$ for 10 minutes and then cooled to $32{ }^{\circ} \mathrm{C}$. Fresh hen yolk at the concentration of 5\%, 1000 $\mathrm{IU} / \mathrm{mL}$ of penicillin (Meiji, Japan), and $1 \mathrm{mg} / \mathrm{mL}$ of streptomycin (Meiji, Japan) were added to the SMEY extender. The SMEY extender was then distributed into eight plastic tubes with the same volume. The first four tubes were added with 4\%,5\%,6\%, and 7\% glycerol (Merck, KgaA, Darmstadt Germany) and designed as SMEY-G4, SMEY-G5, SMEY-G6, and SMEY-G7 respectively. The other four tubes were added with $4 \%, 5 \%, 6 \%$, and $7 \%$ DMF (AppliChem, GmbH, Darmstadt Germany), and designed as SMEY-DMF4, SMEY-DMF5, SMEY-DMF6, and SMEY-DMF7, respectively.

\section{Semen Collection and Evaluation}

The semen was collected once a week from two buffalo bulls with artificial vagina $\left(42-44^{\circ} \mathrm{C}\right)$ in the morning (at $08.00 \mathrm{am}$ ). Immediately after collection, the semen samples were evaluated macro- and microscopically as described by Arifiantini (2012). Macroscopic evaluation included volume, color, $\mathrm{pH}$, and consistency. Semen volume was determined from the graded collection tube soon after collection. Color and consistency were determined visually, and $\mathrm{pH}$ was measured with indicator paper (Merck, scale 6.4-8).

Microscopic evaluation included mass activity, sperm progressive motility, sperm viability, sperm morphology, sperm plasma membrane integrity, and sperm concentration. Mass activity was evaluated by placing a small drop of raw semen on a pre-warmed object glass and evaluated under light microscope at 100×. The sperm progressive motility was estimated by mixing one drop of semen with four drops of saline solution and put on the clean glass slide then covered with cover glass and evaluated subjectively under light microscope at $400 \times$.

The sperm viability and morphology were evaluated at the same slide using eosin-nigrosin staining. One drop of semen and 4 drops of eosin-nigrosin were put on a clean object glass, homogenized, smeared, and dried above heating plate. The smear was then evaluated under light microscope at $400 \times$. The functional integrity of the sperm membrane (PIM) was evaluated using hypo-osmotic swelling (HOS) test. The HOS test was performed by incubating $10 \mu \mathrm{L}$ of semen with 1 $\mathrm{mL}$ of HOS solution (7.35 g of sodium citrate, $13.52 \mathrm{~g}$ of fructose, and $1000 \mathrm{~mL}$ of distilled water, with osmolality of $150 \mathrm{mOsm}$ ) at $37^{\circ} \mathrm{C}$ for 30 minutes. One drop of the mixture was then evaluated under a light microscope at 400×. The swelled and coiled sperm was identified as an intact sperm, while the sperm showing no response was identified as a non-intact sperm. The value of PMI was shown as a percentage of intact sperm (total 200 sperms counted). The sperm concentration was counted subjectively with haemocytometer Neubauer Chamber. All microscopic evaluation was performed by binoculer Microscope (Olympus CH 21, Japan).

\section{Dilution, Freezing, and Post Thawed Evaluation of Frozen Semen}

The raw semen of buffalo bull showing $>60 \%$ sperm motility and $>800 \times 10^{6}$ sperm/mL sperm concentration was selected for further processing. The semen sample was then divided into eight aliquots and each aliquot was diluted with SMEY-G4, SMEY-G5, SMEY-G6, SMEY-G7, SMEY-DMF4, SMEY-DMF5, SMEY-DMF6, and SMEY-DMF7 resulted in a final sperm concentration of $100 \times 10^{6}$ sperm/mL for each treatment. The extended semen was loaded into $0.25 \mathrm{~mL}$ straw (Minitüb, Tiefenbach, Germany) and cooled at $4{ }^{\circ} \mathrm{C}$ for 4 -hr equilibration.

After the equilibration, the straws were then frozen $8 \mathrm{~cm}$ above liquid nitrogen $\left(\mathrm{LN}_{2}\right)$ vapor for 10 minutes and plunged into $\mathrm{LN}_{2}\left(-196{ }^{\circ} \mathrm{C}\right)$. Following $24 \mathrm{~h}$ of storage in $\mathrm{LN}_{2}$ tank, the semen straws were thawed by immersion in a water bath at $37^{\circ} \mathrm{C}$ for $30 \mathrm{~s}$, transferred into $1.5 \mathrm{~mL}$ micro tube, and kept at $37^{\circ} \mathrm{C}$ during evaluation. All semen quality evaluations were performed at prefreezing and post-thawing conditions which included sperm progressive motility, sperm plasma membrane integrity, sperm viability, and recovery rate. These assays were conducted using the same method as initial raw semen evaluation.

\section{Statistical Analysis}

All data were expressed as mean value \pm SEM. Values of post thawed evaluation were analyzed with ANOVA and compared with Duncan's multiple range test if F-value was significant $(\mathrm{P}<0.05)$. All statistical 
analyses were performed with SPSS 16 package program for Windows.

\section{RESULTS}

\section{Characteristics of Buffalo Fresh Semen}

The raw-semen characteristics of swamp-buffalo bull are presented in Table 1 . The characteristics of daily ejaculates varied. The average volume was $2.25 \mathrm{~mL}$, $\mathrm{pH}=6.4$, with a cream color and watery consistency. The average mass activity was ++, sperm progressive motility of $70.33 \%$, sperm viability of $83.25 \%$, sperm plasma membrane integrity of $85.50 \%$, sperm abnormality of $16.80 \%$, and concentration of $1070 \times 10^{6} \mathrm{sperm} / \mathrm{mL}$.

\section{Post Equilibration Motility}

There was no difference in the post-equilibration sperm progressive motility of buffalo bull in SMEY diluents containing different concentrations of glycerol. However, the post-equilibration sperm progressive motilities of buffalo bull in SMEY diluents containing 4 and $5 \%$ DMF were significantly higher $(\mathrm{P}<0.05)$ than in those containing 6 and $7 \%$ DMF (Table 2).

\section{Frozen Semen Quality}

The post-thaw semen qualities of swam buffalo cryopreserved either in extender with glycerol or DMF are shown in Table 3. When the semen was frozen in

Table 1. Fresh semen characteristics of swamp buffalo

\begin{tabular}{lc}
\hline \multicolumn{1}{c}{ Variables } & Mean \pm SEM \\
\hline Volume $(\mathrm{mL})$ & $2.25 \pm 0.09$ \\
Color & Cream \\
Consistency & Watery \\
$\mathrm{pH}$ & $6.40 \pm 0.00$ \\
Mass activity & ++ \\
Sperm motility $(\%)$ & $70.33 \pm 1.71$ \\
Sperm viability $(\%)$ & $83.25 \pm 0.89$ \\
Sperm plasma membrane integrity $(\%)$ & $85.50 \pm 0.41$ \\
Sperm abnormality $(\%)$ & $16.80 \pm 1.14$ \\
Sperm concentration $\left(\times 10^{6}\right.$ sperm $\left./ \mathrm{mL}\right)$ & $1070 \pm 61.99$ \\
\hline
\end{tabular}

extender with DMF, the highest motility was observed in $5 \%$ of concentration of DMF. The motility decreased significantly when the concentration of DMF in the extender increased to $7 \%$. On the other hand, among glycerol groups, the greatest motility was found when the sperms were frozen in the extender with $7 \%$ glycerol $(\mathrm{P}<0.05)$ and the lowest motility was found when the concentrations of glycerol in the extender decreased to $4 \%$ and $5 \%(\mathrm{P}<0.05)$. However, the motility of postthawed semen in the extender with $6 \%$ or $7 \%$ glycerol were similar to those with 5\% DMF. Similar pattern of results was found in the recovery rate parameter.

The viability and membrane plasma integrity of sperm could be seen in Table 3. The viability of sperm ranged from $49 \%$ to $61 \%$. Plasma membrane integrity of sperm ranged from $51 \%$ to $60 \%$. The highest viability and plasma membrane integrity of sperm was obtained in the extender added with glycerol with the concentrations of $6 \%$ and $7 \%(\mathrm{P}<0.05)$ and the lowest was obtained in the extender added with DMF at a concentration of $7 \%(\mathrm{P}<0.05)$.

\section{DISCUSSION}

The ejaculates of swamp buffalo which were collected in this experiment had normal characteristics and appropriate for cryopreservation. Our results support the previous findings by Koonjaenak et al. (2007) and Kaka et al. (2016). Freezing process induces the reduction on the percentages of live sperm. In this study, the percentage of sperm motility, viability, and plasma membrane integrity were significantly $(\mathrm{P}<0.05)$ decrease during equilibration and freezing-thawing processes. During equilibration, cold shock leads to the change of membrane structure and its permeability (Sieme et al., 2015). The functional change of protein membrane

Table 2. Post equilibration sperm motility of swamp buffalo bull semen in SMEY extender with different concentrations of glycerol and DMF (Mean \pm SEM, n=18)

\begin{tabular}{ccccc}
\hline \multirow{2}{*}{ Cryoprotectant } & \multicolumn{4}{c}{ Concentration (\%) } \\
\cline { 2 - 5 } & 4 & 5 & 6 & 7 \\
\hline Glycerol & $64.67 \pm 0.78$ & $64.67 \pm 0.78$ & $67.00 \pm 0.82$ & $67.00 \pm 0.82$ \\
DMF & $64.67 \pm 1.22^{\mathrm{a}}$ & $64.67 \pm 0.78^{\mathrm{a}}$ & $56.33 \pm 0.78^{\mathrm{b}}$ & $57.00 \pm 0.82^{\mathrm{b}}$ \\
\hline
\end{tabular}

Note: Means in the same rows with different supersripts differ significantly $(\mathrm{P}<0.05)$. DMF: dimethylformamide.

Table 3. Frozen-thawed swamp buffalo semen in SMEY extender with different levels of DMF and glycerol (Mean \pm SEM; $\mathrm{n}=18)$

\begin{tabular}{|c|c|c|c|c|c|}
\hline \multirow{2}{*}{ Cryoprotectant } & \multirow{2}{*}{ Level (\%) } & \multicolumn{4}{|c|}{ Variables of spermatozoa (\%) } \\
\hline & & Motility & Viability & PMI & Recovery rate \\
\hline \multirow[t]{4}{*}{ DMF } & 4 & $32.89 \pm 1.19^{\mathrm{b}}$ & $52.10 \pm 1.40^{\mathrm{ab}}$ & $54.49 \pm 1.27^{\mathrm{abc}}$ & $46.76 \pm 1.47^{\mathrm{b}}$ \\
\hline & 5 & $40.44 \pm 1.01^{\mathrm{de}}$ & $55.95 \pm 1.04^{\mathrm{bc}}$ & $57.41 \pm 1.09^{\mathrm{bc}}$ & $57.50 \pm 1.24^{\mathrm{de}}$ \\
\hline & 6 & $34.89 \pm 0.89^{\mathrm{bc}}$ & $53.99 \pm 1.10^{\mathrm{b}}$ & $54.79 \pm 1.09^{\mathrm{abc}}$ & $49.61 \pm 1.09^{\mathrm{bc}}$ \\
\hline & 7 & $27.78 \pm 0.79^{a}$ & $49.08 \pm 0.79 a$ & $51.38 \pm 1.02^{\mathrm{a}}$ & $39.49 \pm 0.97 \mathrm{a}$ \\
\hline \multirow[t]{4}{*}{ Glycerol } & 4 & $31.61 \pm 1.20^{\mathrm{b}}$ & $51.78 \pm 1.75^{\mathrm{ab}}$ & $53.49 \pm 1.17^{\mathrm{ab}}$ & $44.94 \pm 1.48^{\mathrm{b}}$ \\
\hline & 5 & $34.33 \pm 0.96^{\mathrm{b}}$ & $55.15 \pm 1.54^{\text {bc }}$ & $55.18 \pm 0.92^{\mathrm{abc}}$ & $48.82 \pm 1.19^{b}$ \\
\hline & 6 & $37.78 \pm 1.35^{\mathrm{cd}}$ & $58.55 \pm 1.33^{\text {cd }}$ & $58.73 \pm 1.16^{\mathrm{cd}}$ & $53.71 \pm 1.66^{\mathrm{cd}}$ \\
\hline & 7 & $42.33 \pm 1.36^{\mathrm{e}}$ & $61.52 \pm 1.42^{\mathrm{d}}$ & $62.41 \pm 1.47^{\mathrm{d}}$ & $60.19 \pm 1.67 \mathrm{e}$ \\
\hline
\end{tabular}

Note: Means in the same columns with different supersripts differ significantly $(\mathrm{P}<0.05)$. DMF: dimethylformamide, PMI: plasma membrane integrity. 
induces the dysfunction of ion channel regulation that leads to the disruption of sperm motility, viability, and fertility. Membrane leakage was also occurred during cooling process due to the structural change of bilayer membrane into a hexagonal form. Membrane leakage induces change of membrane permeability that leads to the disruption of intracellular activities. Cold shock is occurred at $5-15{ }^{\circ} \mathrm{C}$ (Oldenhof et al., 2013).

Freezing is a major factor causing the sperm damage during cryopreservation. The presence of CPAS is essential to prevent ice crystal formation and maintains the balance of osmotic pressure during freezing. The effects of two cryoprotectants on post-thaw qualities of swamp buffalo semen were examined in the present study. The results clearly demonstrated that even though the semen frozen with $7 \%$ glycerol yielded the highest values of post-thaw sperm viability and plasma membrane integrity compared to the other treatments $(\mathrm{P}<0.05)$, the semen sample with the extender containing 5\% DMF had similar motility compare to those with the extender containing $7 \%$ glycerol $(\mathrm{P}<0.05)$. These results indicate that different cryoprotectant concentrations affect the quality of swamp buffalo after freezing. Blanco et al. (2000) reported that the penetrating cryoprotectants had unique structures and characteristics that could influence the mechanism of interaction with cellular structures, ultimately affecting the sperm cryosurvival. The utilization of glycerol is restricted by its osmotic effect (Macias-Garcia et al., 2012). Glycerol is considered to be not fast enough to replace intracellular water which is push out from cell and leads to the cell shrinkage during freezing. Conversely, during thawing, the cells will swell due to the delay of glycerol excretion from the cell while the extracellular water goes back into the cell (Pegg, 2007). Osmotic pressure of buffalo semen is $289.4 \mathrm{mOsm} / \mathrm{kg}$ and the extender that have osmotic pressure close to that number produce frozen semen with a better quality (Mughal et al., 2013). The lower molecular weight of DMF makes it easily permeates into the cell and prevents osmotic stress (Bezerra et al., 2011). On the other hand, DMF also highly soluble in water and easy to bind with the other molecule, therefore water accumulation which leads to ice crystal formation can be avoided. The presence of DMF in the extender also decreases the concentration of sodium to prevent solution effect (Meryman, 2007). However, the usage of more than 5\% DMF in the extender showed a lower quality of equilibrated and frozen semen.

The results show that DMF has a toxic effect on the sperm with distinct mechanism from glycerol. Fahy (1984) reported that reducing exposure time to higher concentrations of CPAs could contribute to the improved viability. Meanwhile, osmotic stress had no significant effect on the viability of cells exposed to hypertonic medium. It showed that in case of DMF utilization, biochemical toxicity was a major factor of cell damage than osmotic stress. DMF can be toxic after being converted into methyl-isocyanate (MIC) that reduces cellular glutathione (Hantson et al., 2010). During cooling and freezing, DMF will be oxidized by CYP2E1 enzyme into $\mathrm{N}$-methylformamide (NMF) and produce free radicals. These free radicals can induce changes in mitochondrial DNA that are related to sperm motility (Shieh et al., 2007). NMFs are then oxidized into MIC which can reduce cellular glutathione. The reduction of cellular glutathione is induced by its binding with MIC to form S-(N-methylcarbamoyl) gluthatione (SMG). Furthermore, SMG will form N-acetyl-S-(Nmethylcarbamoyl) cysteine (AMCC) which also toxic to the cells (Kim et al., 2007).

The increase in free radical production and the decrease in cellular glutathione production promote oxidative damages especially to the mitochondria. Mitochondrial dysfunction causes the disruption of ATP production that leads to the decrease in energy availability for motility. The exposure to DMF will induce abnormality in the mice embryos cultured in vitro (Klug et al., 1998). Aspartate transaminase (AST) and alanine transaminase (ALT) also increase in the blood serum of the workers exposed to DMF from synthetic leather factory (Zhang et al., 2015). The damaged sperm will release AST from the mitochondria that indicate mitochondrial damages which disrupt ATP production that eventually leads to the loss of sperm energy for motility (Arifiantini \& Purwantara, 2010).

Ferero-Gonzalez et al. (2012) reported that the use of $3 \%$ DMF for cryopreservation of bulls semen produced frozen-thawed sperms with lower motilities than the use of $7 \%$ glycerol. These results are thought to be due to the lower concentration of DMF to prevent ice crystal formation during freezing. The use of DMF for canine semen cryopreservation is not recomended (Mota-Filho et al. 2011) due to the sperm intolerance to DMF either biochemically or due to osmotic imbalance. The use of $6 \%$ DMF produced a better frozen-thawed semen than $6 \%$ glycerol for ram semen cryopreservation in soya milk-based extender; however 6\% DMF produced negative effects on acrosome integrity after thawing (Jerez et al. 2016). This finding is in agreement with Moustacas et al. (2011) which reported that DMF is not an effective cryoprotectant for ram sperm as it is for equine (Arifiantini \& Supriatna 2007), caprine (Ariantie et al. 2013), and swine (Bianchi et al. 2008). The different structures of sperm membrane among species are more likely to be the reason for the poor result.

\section{CONCLUSION}

The type of cryoprotectans (glycerol or DMF) and its different concentrations used in this study affect the quality of frozen-thawed swamp buffalo semen. The concentration of either $7 \%$ glycerol or $5 \%$ DMF was optimum for supporting the sperm motility of swamp buffalo after freezing.

\section{CONFLICT OF INTEREST}

There is no conflict of interest with any financial, personal, or other relationships with other people or organization related to the material discussed in the manuscript. 


\section{ACKNOWLEDGEMENT}

The authors acknowledge the Indonesian Endowment Fund for Education, Indonesian Ministry of Finance for providing the funding. Thanks to Mrs Nia, Ms Yanti and all staffs at Large Ruminant Unit Indonesian Research Institute for Animal Production for their valuable technical support.

\section{REFERENCES}

Akhter, S., M.S. Ansari, B.A. Rakha, S.M.H. Andrabi, S. Iqbal, \& N. Ullah. 2010. Cryopreservation of buffalo (Bubalus bubalis) semen in Bioxcell ${ }^{\circledR}$ extender. Theriogenology 74: 951-955. http://doi:10.1016/j.theriogenology.2010.04.024

Ariantie, O.S., T.L. Yusuf, D. Sajuthi, \& R.I. Arifiantini. 2013. Effect of glycerol and dimethylformamide cryoprotectants on buck Etawah Crossbreed frozen semen using modified tris Diluents. JITV. 18: 239-250. https://doi.org/10.14334/ jitv.v18i4.327

Arifiantini, R.I. \& B. Purwantara. 2010. Motility and viability of Friesian Holstein spermatozoa in three different extender stored at $5{ }^{\circ} \mathrm{C}$. J. Indones. Trop. Anim. Agric. 35: 222-226. https://doi.org/10.14710/jitaa.35.4.222-226

Arifiantini, R.I. \& I. Supriatna. 2007. Stallion semen cryopreservation using different cryoprotective agents on the skim milk trehalosa extender. JITV. 12: 139-146.

Arifiantini, R.I. 2012. Teknik Koleksi dan Evaluasi Semen pada Hewan. IPB Press, Bogor.

Baruselli P.S., N.A.T. Carvalho, L.U. Gimenes, \& G.A. Crepaldi. 2007. Fixed-time artificial insemination in buffalo. Ital. J. Anim Sci. 6 suppl 2:107-118. https://doi. org/10.4081/ijas.2007.s2.107

Bezerra F.S.B., T.S. Castelo, H.M. Alves, I.R.S. Oliveira, G.L. Lima, G.C.X. Peixoto, A.C.S.D. Bezerra, \& A.R. Silva. 2011. Objective assessment of the cryoprotective effects of dimethylformamide for freezing goat semen. Cryobiology 6: 263-266. https://doi.org/10.1016/j.cryobiol.2011.09.136

Bianchi, I., K. Calderam, E.F. Maschio, E.M. Madeira, R. da Rosa Ulguim, C.D. Corcini, D.C. Bongalhardo, E.K. Correa, T. Lucia Jr, J.C. Deschamps, \& M.N. Correa. 2008. Evaluation of amides and centrifugation temperature in boar semen cryopreservation. Theriogenology 69: 632-638. https://doi.org/10.1016/j.theriogenology.2007.11.012

Blanco, J.M., G. Gee, D.E. Wildt, \& A.M. Donoghue. 2000. Species variation in osmotic, cryoprotectant, and cooling rate tolerance in poultry, eagle, and peregrine falcon spermatozoa. Biol. Reprod. 63:1164-71.

Fahy, G.M. 1984. Cryoprotectant toxicity: biochemical or osmotic? Cryo Letters 5: 79-90.

Ferero-Gonzalez, R.A., E.C.C. Celeghini, C.F. Raphael, A.F.C. Andrade, F.F. Bressan, \& R.P. Arruda. 2012. Effect of bovine sperm cryopreservation using different freezing techniques and cryoprotective agents on plasma, acrosomal and mitochondrial membranes. Andrologia 44:154-159. https://doi.org/10.1111/j.1439-0272.2010.01154.x

Gibb, Z., L.H.A. Morris, W.M.C. Maxwell, \& C.G. Grupen. 2013. Dimethyl formamide improves the postthaw characteristics of sex-sorted and nonsorted stallion sperm. Theriogenology. 79: 1027-1033. https://doi.org/10.1016/j. theriogenology.2013.01.013

Gordon, I. 1996. Controlled Reproduction in Cattle and Buffaloes. CAB International, Oxon, OX, UK.

Hantson, P., A. Villa, A.C. Galloy, S. Negri, G. Esabon, F. Lambiotte, V. Haufroid, \& R. Garnier. 2010. Dimethylformamide metabolism following self-harm using a veterinary euthanasia product. Clin. Toxicol. 48: 725729. https://doi.org/10.3109/15563650.2010.498790
Hoque, M.N., A.K. Talukder, M. Akter, \& M. Shamsuddin. 2014. Evaluation of ovsynch protocols for timed artificial insemination in water buffaloes in Bangladesh. Turk. J. Vet. Anim. Sci. 38: 418-424. https://doi.org/10.3906/vet-1302-35

Jerez, R., N. Gonzalez, M. Olaciregui, V. Luno, I. de Blas, \& L. Gil. 2015. Use of soy milk combined with different cryoprotectants for the ram semen cryopreservation. Small. Rum. Res. 134:34-38. https://doi.org/10.1016/j. smallrumres.2015.12.003

Kaka, A., A.A. Memon, P. Khatri, H.K. Kumbhar, D.H. Kalhoro, M. Tariq, S.A. Pirzado, \& A.N. Tunio. 2016. Determination of quality characteristics of Khundi buffalo bull semen. JBAS. 12: 394-397.

Kim, T.H. \& S.G. Kim. 2011. Clinical outcomes of occupational exposure to $\mathrm{N}, \mathrm{N}$-dimethylformamide: perspectives from experimental toxicology. SHAW. 2: 97-104. https://doi. org/10.5491/SHAW.2011.2.2.97

Klug, S., H.J. Merker, \& R. Jackh. 1998. Potency of monomethyl-, dimethylformamide and some of their metabolites to induce abnormal development in a limb bud organ culture. Toxicol. in Vitro. 12: 123-132. https://doi.org/10.1016/ S0887-2333(97)00094-5

Koonjaenak, S., V. Chanatinart, S. Aiumlamai, T. Pinyopumimintr, \& H. Rodriguez-Martinez. 2007. Seasonal variation in semen quality of swamp buffalo bulls (Bubalus bubalis) in Thailand. Asian J. Androl. 9: 92-101. https://doi.org/10.1111/j.1745-7262.2007.00230.x

Kumar, D., P. Kumar, P. Singh, S.P. Yadav, \& P.S. Yadav. 2016. Assessment of sperm damages during different stages of cryopreservation in water buffalo by fluorescent probes. Cytotechnology 68: 451-458. https://doi.org/10.1007/ s10616-014-9798-9

Macias-Garcia, B., F.C. Ortega, I.M. Aparicio, A. Miro-Moran, R.A. Morillo, B.J.M. Gallardo, F.L. Gonzales, C.M. Balao da Silva, H. Rodriguez-Martinez, J.A. Tapia, \& F.J. Pena. 2012. Toxicity of glycerol for the stallion spermatozoa: effect of membrane integrity and cytoskeleton, lipid peroxidation and mitochondrial membrane potential. Theriogenology 77: 1280-1289. https://doi.org/10.1016/j. theriogenology.2011.10.033

Meryman, H.T. 2007. Cryopreservation of living cells: principles and practice. Transfusion 47: 935-945. https://doi. org/10.1111/j.1537-2995.2007.01212.x

Mota-Filho, A.C., C.H.A. Teles, R.P. Juca, J.F.S. Cardoso, D.C. Uchoa, C.C. Campello, A.R. Silva, \& L.D.M. Silva. 2011. Dimethylformamide as a cryoprotectant for canine semen diluted and frozen in ACP-106C. Theriogenology 76:13671372. https://doi.org/10.1016/j.theriogenology.2011.05.010

Moustacas, V.S., B.C. Cruz, F.C. Varago, D.A. Miranda, P.G. Lage, \& M. Henry. 2011. Extenders containing dimethylformamide associated or not with glycerol are ineffective for ovine sperm cryopreservation. Reprod. Dom. Anim. 46:924925. https://doi.org/10.1111/j.1439-0531.2011.01785.x

Mughal, D.H., A. Ijaz, M.S. Yousaf, H. Rehman, M. Aleem, H. Zaneb, \& F. Wadood. 2013. Assessment of optional osmotic pressure of citrate egg yolk extender for cryopreservation of buffalo bull (Bubalus bubalis) semen. JAPS. 23: 964-968.

Oh, S.A., S.H. Choi, M.H. Ko, T.Y. Kang, S.R. Cho, M.S. Ko, Y.M. Oh, \& W.M. Cho. 2012. Effect of amides as a cryoprotectant on quality of frozen-thawed sperm in korean jeju black bull. J. Anim. Sci. Tech. 54: 95-101. https://doi. org/10.5187/JAST.2012.54.2.95

Oldenhof, H., M. Gojowsky, S. Wang, S. Henke, C. Yu, K. Rohn, W.F. Wolkers, \& H. Sieme. 2013. Osmotic stress and membrane phase changes during freezing of stallion sperm: mode of action of cryoprotective agents. Biol. Reprod. 88: 1-11. https://doi.org/10.1095/biolreprod.112.104661

Paul, V. \& B.S. Prakash. 2005. Efficacy of the ovsynch protocol for synchronization of ovulation and fixed-time 
artificial insemination in Murrah buffaloes (Bubalus bubalis). Theriogenology 64:1049-1060. https://doi.org/10.1016/j. theriogenology.2005.02.004

Pegg, D.E. 2007. Principles of cryopreservation. In: Day JG, Stacey GN, editor. Cryopreservation and Freeze-Drying Protocols 2nd Ed. Humana Press, New Jersey, US.

Rasul, Z., N. Ahmed, \& M. Anzar. 2007. Antagonist effect of DMSO on the cryoprotection ability of glycerol during cryopreservation of buffalo sperm. Theriogenology 68:813-819. http://doi:10.1016/j.theriogenology.2007.06.014

Reddy, N.S.S., G. J. Mohanarao, \& S.K. Atreja. 2010. Effects of adding taurine and trehalose to a tris-based egg yolk extender on buffalo (Bubalus bubalis) sperm quality following cryopreservation. J. Anim. Reprod. Sci. 119:183-190. https://doi.org/10.1016/j.anireprosci.2010.01.012

Rossi, P., D. Vecchio, G. Neglia, R. Di Palo, B. Gasparrini, M.J. D'Occhio, \& G. Campanile. 2014. Seasonal fluctuations in the response of Italian Mediterranean buffaloes to synchronization of ovulation and timed artificial insemination. Theriogenology 82: 132-137. https://doi.org/10.1016/j. theriogenology.2014.03.005

Shahverdi, A., A. Rastegarnia, \& T.R. Topraggaleh. 2014. Effect of extender and equilibration time on post thaw motility and chromatin structure of buffalo (Bubalus bubalis) bull spermatozoa. J. Cell. 16: 279-288.
Shieh, D.B., C.C. Chen, T.S. Shih, H.M. Tai, Y.H. Wei, \& H.Y. Chang. 2007. Mitochondrial DNA alteration in blood of the human exposed to $\mathrm{N}, \mathrm{N}$-dimethylformamide. Chem. Biol. Interact. 165: 211-219. https://doi.org/10.1016/j. cbi.2006.12.008

Sianturi, R.G., B. Purwantara, I. Supriatna, Amrozi, \& P. Situmorang. 2012. Effect of glutathione and bovine seminal plasma in lactose extender on viability of swamp buffalo frozen semen. JITV. 17: 169-178.

Sieme, H., H. Oldenhof, \& W.F. Wolkers. 2015. Sperm membrane behaviour during cooling and cryopreservation Reprod Dom Anim. 50: 20-26. https://doi.org/10.1111/ rda. 12594

Singh, I. \& A.K. Balhara. 2016. New approach in buffalo artificial insemination programs with special reference in India. Theriogenology 86: 194-199. https://doi.org/10.1016/j. theriogenology.2016.04.031

Yulnawati, Y., H. Maheshwari, M. Rizal, \& A. Boediono. 2013. The success rate of artificial insemination using postthawed spotted buffaloes epididymal sperm. Med. Pet. 36:101-105 http://dx.doi.org/10.5398/medpet.2013.36.2.101

Zhang, H., Q. Liu, Y. Duan, H. Dong, \& Y. Zhou. 2015. Chronic occupational N,N-dimethylformamide poisoning induced death: a case report. Forensic Sci. Med. Pathol. 11: 584-588. https://doi.org/10.1007/s12024-015-9705-5 